TAPROBANICA, ISSN 1800-427X. January, 2015. Vol. 07, No. 01: pp. 60-61.

(C) Research Center for Climate Change, University of Indonesia, Depok, Indonesia \& Taprobanica Private Limited, Homagama, Sri Lanka

www.taprobanica.org

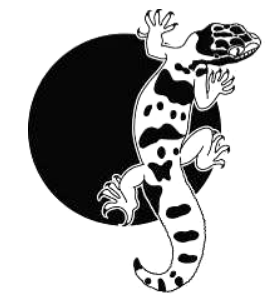

\section{On latex licking in the five-striped palm squirrel (Funambulus pennantii)}

The five-striped palm squirrel, Funambulus pennantii and three-striped palm squirrel, $F$. palmarum, consume liquid food in the form of nectar and latex in addition to solid food (Prater, 1980; Balasubramanian, 1995; Sharma, 2007). The latexy secretion from the abaxial surface of the leaves at the junction of petiole and lamina of the leaves of the Banyan, Ficus benghalensis (Moraceae) is licked by both $F$. pennantii and $F$. palmarum as food. A scar is seen on the licked site of every leaf which appears to be a result of repeated licking and drying of the residue of the secretion (Sharma, 2007).

While studying this behaviour in other species of Ficus in the state of Rajasthan, it was noticed that leaves of Ficus mollis are also licked. A prominent scar is visible on the licked site of Ficus mollis leaves towards abaxial surface at the junction of petiole and lamina. This licking behaviour of $F$. pennantii was seen in the Sariska Tiger Reserve, Renagiri and Siliser in Alwar District; Nahargarh and Jamwa Ramgarh Wildlife Sanctuaries in Jaipur district; Ranthambore National Park and Sawai Man Singh Wildlife Sanctuary in Sawai Madhopur district; and Patan in Sikar district.

As many as 15 species of Ficus are found in Rajasthan, namely $F$. amplissima Smith, $F$. arnottiana (Miq.) Miq., F. benghalensis L., $F$. drupacea Thunb., F. hispida L.f., F. microcarpa L.f., $F$. mollis Vahl, $F$. palmata Forsk., $F$. racemosa L., F. religiosa L., F. rumphii Blume., $F$. tsjahela Burm.f., $F$. virens Ait., $F$. pumilla L. and F. carica L. (Shetty \& Singh, 1991). Out of 15 species, only two, $F$. benghalensis, and $F$. mollis, are tapped for liquid food by the squirrels in the state.

Why are only two species selected to get the liquid food from the abaxial surface of leaves at the junction of petiole and lamina and not the others? The answer is hidden in the gladular nature of the petioles of the leaves of these two species. Both these Ficus species have a secretory gland at the junction of petiole and lamina. A longitudinal gland with a depressed centre (when fresh) is situated at the base of midrib or at the junction of several principle nerves beneath Ficus mollis leaves. Similarly, a large flat, smooth gland is present at the confluence of the many nerves which meet in $F$. benghalensis leaves towards the abaxial side (Sexena \& Brahmam, 1995).

The squirrels like the latexy secretion which provides them with nutrition. To get the nutrition from the leaves, the squirrels tap them when they are green and intact on the trees, and the latexy secretion is procured during the daytime.

Ficus mollis prefers almost vertical inaccessible sites in the Aravallis and Vindhyas in the state, and is absent from the western Thar desert (Bhandari, 1990; Shetty \& Singh, 1991; Singh \& Shrivastava 2007; Tiagi \& Aery 2007). The $F$. pennantii is a common squirrel in the distributional range of Ficus mollis in Rajasthan. It commonly feeds on the secretion produced by the glandular portion of petiolelamina junction and, to get more and fresh secretion, it sometimes makes a gentle scratching using its incisors, as well as repeated licking, causing a prominent scar on the glandular portion of the leaves. The youngest leaves do not have scars indicating that the abilty to secrete appears in the leaves only when they attain full development. Other Ficus species of Rajasthan do not have secretory petiolar glands and are not tapped by the squirrels and so remain scar-free.

\section{Acknowledgements}

The authors are very grateful to Sh. Udai Ram Jat (Assistant Conservator of Forests), for his kind help while conducting this study in Sariska 
Tiger Reserve, Alwar; Jamwa Ramgarh Sanctuary Jaipur; Ranthmbhor National Park and Sawai Man Singh Wildlife Sanctuary in Sawai Madhopur District.

\section{Literature cited}

Balasubramanian, P., 1995. Some notes on the fruits, seeds and nectar consumed by Three-striped palm squirrel Funambulus palmarum at Point Calimere Wildlife Sanctuary, Tamil Nadu. Journal of the Bombay Natural History Society, 95: 256258.

Bhandari, M.M., 1990. Flora of The Indian Desert (Revised Edition). MPS Repros, Jodhpur. Pp 1435.

Prater, S.H., 1980. The book of Indian Animals. Bombay Natural History Society and Oxford University Press, Mumbai.

Saxena, H.O. and M.Brahmam, 1995. The Flora of Orissa. Vol. III. Regional Research Laboatory, Bhubaneshwar. Pp. 1323-2008.

Sharma, S.K., 2007. A note on the latex licking habit of Five-striped and Three-striped Palm Squirrels. Journal of the Bombay Natural History Society 104: 82-83.

Shetty, B.V. and V.Singh, 1991. Flora of Rajasthan. Vol. II. Pp 453-860.

Singh, V. and A.K. Shrivastava, 2007. Biodiversity of Ranthambhore Tiger Reserve, Rajasthan. Scientific Publishers, Jodhpur. Pp. 1415.

Tiagi, Y.D. and N.C. Aery, 2007. Flora of Rajasthan. Himanshu Publications, Udaipur and Delhi. Pp. 1-725.

Submitted: 7 July 2014, Accepted: 24 July 2014 Section Editor: Colin Groves

S. K. Sharma ${ }^{1} \&$ V. K. Koli ${ }^{2}$

${ }^{1}$ Wildlife Sanctuary Jaisamand, Jaisamand Post, Udaipur district, Rajasthan 313905, India E-mail: sksharma56@gmail.com

${ }^{2}$ Wildlife Research Laboratory, Department of Zoology, Mohanlal Sukhadia University Udaipur (Rajasthan) 313001; E-mail: vijaykoli87@yahoo.in 